\title{
PENGARUH PEMBERIAN SUPLEMEN ELECROLYTE FUEL SYSTEM (EFS) TERHADAP PENINGKATAN DAYA TAHAN KECEPATAN ATLET BALAP SEPEDA KOTA PADANG
}

\author{
Apri Agus, Rifhaatul Hanifa ${ }^{5)}$
}

\begin{abstract}
ABSTRAK
Penelitian ini dilatarbelakangi oleh atlet balap sepeda Kota Padang yang masih kurang mampu memaksimalkan kemampuan daya tahan kecepatan dengan baikdalam perlombaan rersmi. .Penelitian ini bertujuan untuk mengetahui apakah ada pengaruh pemberian suplemen Electrolyte Fuel System terhadap daya tahan kecepatan atlet balap sepeda Kota Padang.

Jenis penelitian ini merupakan penelitian eksperimen semu. Bertempat di camp latihan di Tabing, Padang, dilakukan pada bulan Mei 2017. Populasi dalam penelitian ini adalah seluruh atlet balap sepeda Kota Padang, yang berjumlah sebanyak 5 orang.Dalam pengambilan sampel penulis menggunakan teknik Total Sampling, dengan jumlah keseluruhan populasi diambil sebagai sampel yaitu berjumlah 5 orang.Data penelitian didapatkan dengan melakukan tes awal (Pre Test) dengan mengukur daya tahan kecepatan serta melakukan tes akhir (Post Test) mengukur daya tahan kecepatan. Analisa data dilakukan dengan cara mengukur daya tahan kecepatan atlet, sebelum diberikan suplemen EFS dan saat diberikan suplemen EFS. Data yang diperoleh dianalisis dengan rumus uji beda (uji t).

Hasil analisis data penelitian diperoleh $\mathrm{t}_{\text {hitung }}=9,81>\mathrm{t}_{\text {tabel }}=2,78$ (hipotesis penelitian diterima). Hasil penelitian ini membuktikan bahwa terdapat pengaruh yang signifikan dari pemberian suplemen EFS terhadap peningkatan daya tahan kecepatan atlet balap sepeda Kota Padang, ini ditandai dengan hasil yang diperoleh yaitu $t_{\text {hitung }}=$ 9,81 untuk tabel pada tarif signifikan $\alpha=0.05$ derajat kebebasan $(\mathrm{dk})=\mathrm{n}-1=5-1=$ $4=2.78$, ini artinya terdapat pengaruh yang berarti antara pemberian suplemen EFS terhadap peningkatan daya tahan kecepatan atlet balap sepeda Kota Padang.
\end{abstract}

Kata Kunci : Suplemen EFS, Daya Tahan Kecepatan

\section{PENDAHULUAN}

Olahraga merupakan kegiatan mengolah tubuh yang bertujuan mulai dari untuk meningkatkan kebugaran dan kesehatan sampai meningkatkan prestasi diberbagai cabang olahraga. Prestasi olahraga akan dapat tercapai apabila melalui proses tertentu mulai dari pencarian bakat, proses latihan yang terprogram dalam kurun waktu tertentu dengan pelatih yang kompeten dan aktif mengikuti kompetisi

5) Apri Agus. Saat ini Dosen Jurusan Kesehatan dan Rekreasi Fakultas Ilmu Keolahragaan Universitas Negeri Padang

5) Rifhaatul Hanifa. Saat ini Mahasiswa Jurusan Kesehatan dan Rekreasi Fakultas Ilmu Keolahragaan Universitas Negeri Padang 
baik ditingkat nasional maupun internasional. Tujuan mengikuti kompetsi adalah guna mengetahui sampai sejauhmana hasil latihan yang dilakukan selama ini...

Hal ini juga tertuang dalam Undang - Undang RI tahun 2005 No 3, tentang Sistem Keolahragaan Nasional menyebutkan bahwa "olahraga adalah segala kegiatan yang sistematis mendorong, membina serta mengembangkan potensi jasmani, rohani dan sosial. Lengkapnya dalam Bab Vll pasal 1 menyebutkan :"Olahraga prestasi adalah yang membina dan mengembangkan olahragawan secara terencana, befrjenang, dan berkelanjutan melalui kompetisi untuk mencapai prestasi dengan dukungan ilmu pengetahuan dan teknologi olahraga'

Dalam Undang-Undang Sistem Keolahragaan Nasional Nomor 3 tahun 2005 pasal 27 ayat 4 tentang pembinaan dan pengembangan olahraga prestasi menyatakan bahwa: "pembinaan dan pengembangan olahraga prestasi dilaksanakan dengan memberdayakan perkumpulan olahraga, menumbuh kembangkan serta olahraga yang bersifat nasional dan daerah dan penyelenggaraan kompetisi secara berjenjang dan berkelanjutan".

Balap sepeda. adalah merupakan salah satu cabang olahraga yang secara historis pernah Berjaya di Sumataera Barat pada masa lalu. Banyak atlet balap sepeda yang berasal dari Sumatera barat diantaranya Dasrizal dari Payakumbuh daan lainnya. Akan tetapi akhir-akhir ini perkembanngan prestasi balap sepeda di Sumbar diakui mengalami penurunan dalam segala hal baik peminat maupun prestasinya. Namun beberapa tahun terakhir Pemerintah Sumatera Barat melalui Dinas Parawisata Sumatara Barat secara rutin menggelar kejuaraan balap sepeda yang dikenal dengan istilah Tour de Singkarak. Kejuaraan ini diakui memang ada nuansa pariwisatanya di samping missi olahraganya. Dampaknya adalah mulai kembali bergerak perkembangan olahraga balap sepeda dan peminatnya mulai bertambah dari waktu ke waktu. Hal ini terbukti sudah ada pembalap Sumbar yang ikut lomba balap sepeda Tour De Singkarak (TDS). Tour ini merupakan kerjasama antara Kementrian Pariwisata, Kementrian Pemuda dan Olahraga dan PB ISSI (Ikatan Sport Sepeda

5) Apri Agus. Saat ini Dosen Jurusan Kesehatan dan Rekreasi Fakultas Ilmu Keolahragaan Universitas Negeri Padang

5) Rifhaatul Hanifa. Saat ini Mahasiswa Jurusan Kesehatan dan Rekreasi Fakultas Ilmu Keolahragaan Universitas Negeri Padang 
Indonesia) yang diresmikan oleh Bapak Mentri Pemuda dan Olahraga Adiyaksa Dault pada tanggal 3 Juni 2009 di Pantai Padang Provinsi Sumatera Barat yang masih dihelat setiap tahun hingga tahun 2016. Terselenggaranya ajang Tour De Singkarak (TDS) bentuk keseriusan Pemerintah dalam menghasilkan pembalap sepeda jalan raya yang berkualitas Internasional serta meningkatkan prestasi balap sepeda di Indonesia khususnya Sumatera Barat di masa akan datang.

Menurut Soeroso dalam Aziz (2013:4) balap sepeda adalah sebuah perlombaan untuk mencapai tujuan batas akhir finish dalam waktu secepat-cepatnya dengan menggunakan sepeda. Balap sepeda sendiri terdiri dari berbagai macam jenis, ada balap sepeda marathon, tour de france, sepeda gunung, trail, dan speed. Olahraga balap sepeda merupakan olahraga yang membutuhkan daya tahan yang tinggi, karena olahraga ini adalah olahraga yang menggunakan waktu yang lama.

Kota Padang merupakan daerah yang memiliki Pengurus Pencab ISSI balap sepeda dan telah mengikuti pelombaan baik di tingkat provinsi, nasional maupun internasional.Tour De Singkarak adalah salah satu event internasional yang selalu ditunggu dan diikuti oleh atlet balap sepeda Kota Padang, namun sangat disayangkan tim balap sepeda kota padang belum pernah ada yang bisa menaiki podium di setiap etape yang diperlombakan dan bahkan ada yang do not finish dan tidak bisa lagi mengikuti perlombaan di etape selanjutnya, hal ini terjadi diduga karena beberapa hal yaitu kurangnya daya tahan kecepatan, kurangnya kecepatan, keadaan kondisi fisik yang kurang baik, nutrisi untuk tubuh belum tercukupi.

Dari beberapa faktor diatas pemberian nutrisi tambahan sangat mempengaruhi terhadap kondisi tubuh saat latihan maupun bertanding. Adapun nutrisi yang dominan mempengaruhi daya tahan kecepatan adalah makanan dan minuman suplemen. Yang termasuk dalam minuman suplemen yaitu Electrolyte Fuel System, Whey Protein, Amino dan lain sebagainya Suplemen tersebut tidak termasuk dilarang dalam balab sepeda..

5) Apri Agus. Saat ini Dosen Jurusan Kesehatan dan Rekreasi Fakultas Ilmu Keolahragaan Universitas Negeri Padang

5) Rifhaatul Hanifa. Saat ini Mahasiswa Jurusan Kesehatan dan Rekreasi Fakultas Ilmu Keolahragaan Universitas Negeri Padang 
Dalam Grek (2015:50) mengemukakan bahwa menggunakan suplemen seperti creatine, vitamin, minuman suplemen whey protein adalah cara yang efektif untuk meningkatkan kinerja atlet. Pemberian minuman suplemen pada olahragawan bertujuan untuk mencegah dehidrasi.Dehidrasi ringan dapat mempengaruhi peforma atlet. Cairan, selain mengandung air, juga mengandung bahan lain yang diperlukan tubuh yaitu elektrolit. Elektrolit dalam cairan tubuh terdiri atas kation dan anion.Kation utama dalam cairan tubuh berupa sodium, potassium, sedangkan anion utama adalah klorida.

Electrolyte Fuel System (EFS) adalah salah satu minuman suplemen olahraga yang mengandung elektrolit yang dibutuhkan oleh tubuh, minuman EFS ini berbentuk serbuk yang dapat diminum dengan cara dilarutkan kedalam air, minuman ini memberi fungsi yang dibutuhkan oleh tubuh, yang dapat meningkatkan daya tahan dan meningkatkan kinerja selama latihan, maupun bertanding, kemudian dari pada itu minuman ini dapat menyeimbangkan cairan di dalam tubuh, sehingga tubuh tidak mengalami dehidrasi. Untuk itu penulis ingin mencoba memberikan minuman suplemen EFS terhadap atlet balap sepeda kota Padang ..

Tujuan dari penelitian ini adalah untuk mengetahui apakah ada pengaruh yang diberikan oleh suplemen Electrolyte Fuel System (EFS) terhadap daya tahan kecepatan atlet sepeda balap kota Padang.

\section{METODOLOGI}

Jenis penelitian yang digunakan dalam penelitian ini eksperimen semu (quasi eksperimental). Menurut Sugiyono (2008:107) menyatakan bahwa metode eksperimen yaitu metode penelitian yang digunakan untuk mencari pengaruh perlakuan tertentu terhadap yang lain dalam kondisi yang terkendalikan. Perlakuan yang dimaksud disini adalah pemberian suplemen EFS. Dengan pemberian suplemen tersebut akan terlihat hubungan sebab akibat sebagai pengaruh dari pemberian suplemen. Penelitian ini bertujuan untuk mengetahui pengaruh pemberian suplemen

5) Apri Agus. Saat ini Dosen Jurusan Kesehatan dan Rekreasi Fakultas Ilmu Keolahragaan Universitas Negeri Padang

5) Rifhaatul Hanifa. Saat ini Mahasiswa Jurusan Kesehatan dan Rekreasi Fakultas Ilmu Keolahragaan Universitas Negeri Padang 
Electrolyte Fuel System terhadap daya tahan kecepatan atlet Balap Sepeda kota Padang.

Desain penelitian yang digunakan adalah desain eksperimen. Desain yang dimaksud terkait pada bagan berikut :

S

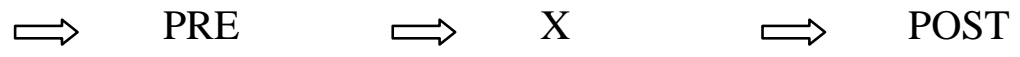

The One Group Pre Test and Post Test Degsign

Penelitian ini dilakukan di Kota Padang.Waktu penelitian dilaksanakan pada hari Rabu dan Jum'at tanggal 24 dan 26 Mei 2017. Dalam penelitian ini yang menjadi populasinya adalah seluruh Atlet balap sepeda Kota Padang yang aktif latihan dan terdaftar pada Pengcab Kota Padang. Berdasarkan wawancara dengan pelatih jumlah atlet balap sepeda Kota Padang yang terdaftar adalah sejumlah 5 orang yang terdiri dari atlet putra secara keseluruhan. Teknik pengambilan sampel menggunakan total sampling, yang mana seluruh populasi dijadikan sampel. Sampel diambil dari semua populasi atlet balap sepeda yang aktif latihan.Dengan demikian jumlah sampel dalam penelitian ini berjumlah sebanyak 5 orang.

Instrumen dalam penelitian adalah tes balap sepeda jarak 100km dengan menggunakan alat trainer dan roller, kemudian perlengkapan yang dibutuhkan dalam penelitian ini adalah alat tulis, stopwatch, sepeda balap, trainer, roller dan speedometer.

Jenis data dalam penelitian ini adalah data primer.Data primer yaitu data yang diperoleh peneliti dari sampel melalui tes. Data yang digunakan dalam penelitian ini berasal dari tes balap sepeda jarak $100 \mathrm{~km}$. Teknik analisis data ini menggunakan statistik uji t (uji beda) dengan formula :

$t_{\text {hitung }}=\frac{\left|\bar{x}_{1}-\bar{x}_{2}\right|}{\sqrt{\frac{\sum D^{2}-\frac{\left(\sum D\right)^{2}}{n}}{n(n-1)}}}$

5) Apri Agus. Saat ini Dosen Jurusan Kesehatan dan Rekreasi Fakultas Ilmu Keolahragaan Universitas Negeri Padang

5) Rifhaatul Hanifa. Saat ini Mahasiswa Jurusan Kesehatan dan Rekreasi Fakultas Ilmu Keolahragaan Universitas Negeri Padang 


\section{HASIL PENELITIAN DAN PEMBAHASAN}

\section{Tes Awal Daya Tahan Kecepatan}

Variable daya tahan kecepatan diukur dengan tes memakai alat bernama trainer dan roller. Hasil pengukuran variable daya tahan kecepatan dari 5 orang sampel sebelum dilakukan pemberian suplemen skor waktu tertinggi adalah 192,05 dan skor waktu terendah 206,11. Distribusi skor menghasilkan rata-rata (mean) 199,26 dan simpangan baku atau standar deviasi adalah 5,76.

\section{Tes Akhir Daya Tahan Kecepatan}

Berdasarkan data penelitian untuk data akhir (post test) daya tahan kecepatan atlet balap sepeda Kota Padang skor waktu tertinggi adalah 186,20 sedangkan skor terendah adalah 202,34, dengan rata-rata (mean) sebesar 193,27, simpangan baku atau standardeviasi 6,58.

\section{Uji Normalitas}

Uji normalitas yang dilakukan untuk mengetahui apakah data yang diambil berasal dari data yang berdistribusi normal atau tidak. Untuk menguji kenormalan data dalam penelitian diuji dengan uji liliefours, hasil uji kenormalan data daya tahan kecepatan awal (pre test) adalah 0,088 dengan probabilitas (sig.) 0.337, dengan $\alpha 0.05$ dan uji kenormalan daya tahan kecepatan akhir (post test) adalah 0,1398 dengan pobabilitas (sig.) yang sama yaitu 0.337 dan $\alpha 0.05$, dari data tersebut dapat ditarik kesimpulan data pre test dan post test berdistribusi normal. Penarikan kesimpulan ini berdasarkan kriteria uji kenormalan data dalam uji liliefours $\mathrm{L}_{\mathrm{o}}<\mathrm{L}_{\text {tabel. }}$

\section{Pengujian Hipotesis}

Setelah melakukan pengujian data dan data berdistribusi normal, maka dilanjutkan dengan pengujian hipotesis. Adapun hipotesis dalam penelitian ini adalah : terdapat pengaruh yang signifikan pada pemberian suplemen EFS terhadap peningkatan daya tahan kecepatan atlet balap sepeda Kota Padang. Untuk menguji apakah keberadaan hipotesis yang diajukan dalam penelitian ini dapat diterima atau tidak maka dilakukan pengujian hipotesis yang diajukan.

5) Apri Agus. Saat ini Dosen Jurusan Kesehatan dan Rekreasi Fakultas Ilmu Keolahragaan Universitas Negeri Padang

5) Rifhaatul Hanifa. Saat ini Mahasiswa Jurusan Kesehatan dan Rekreasi Fakultas Ilmu Keolahragaan Universitas Negeri Padang 
Pengolahan data dilakukan dengan menghitung pengaruh pemberian suplemen EFS terhadap peningkatan daya tahan kecepatan atlet balap sepeda Kota Padang. Nilai $t_{\text {hitung }}$ antara tes awal (pre test) dan tes akhir (post test) pemberian suplemen EFS terhadap daya tahan kecepatan atlet balap sepeda Kota Padang menunjukkan angka sebesar 9,81, selanjutnya nilai yang diperoleh dibandingkan dengan $\mathrm{t}_{\text {tabel }}$ dengan $\alpha 0.05$ dengan derajat kebebasan (4) ternyata nilai yang diperoleh adalah 2,78, hal ini menunjukakn bahwa nilai $t_{\text {hitung }}(9,81)>t_{\text {tabel }}(2,78)$ dengan demikian dapat disimpulkan bahwa hipotesis yang diajukan terdahulu terdapat pengaruh yang signifikan antara pemberian suplemen EFS terhadap peningkatan daya tahan kecepatan atlet balap sepeda Kota Padang. Dengan arti kata pemberian EFS dapat meningkatkan daya tahan kecepatan dalam balap sepeda..

\section{PEMBAHASAN}

Berdasarkan hasil analisis yang diperoleh dari penelitian ini secara nyata terlihat adanya peningkatan kemampuan daya tahan kecepatan dari tes awalsebelum diberikan suplemen dan tes akhir pada saat diberikan suplemen, terdapat pengaruh dari pemberian suplemen terhadap peningkatan daya tahan kecepatan.Artinya suplemen EFS yang diberikan ternyata dapat meningkatkan kemampuan daya tahan kecepatan.

Hal ini dibuktikan juga dengan adanya peningkatan kecepatan rata-rata atlet dan perubahan waktu yang dicapai oleh masing-masing atlet pada saat sebelum diberikan perlakuan dan pada saat pemberian perlakuan terhadap sampel, sebelum mengetahui hasil akhir tentunya dilakukan tes awal untuk mengetahui tingkat daya tahan kecepatan. Dapat dilihat juga pada skor waktu yang diperoleh masing-masing atlet, meningkat jauh pada saat pemakaian suplemen.

Selain peningkatan waktu pada daya tahan kecepatan, terdapat juga perbedaan dari keadaan kondisi fisik sebelum dan pada saat pemberian suplemen yaitu atlet

5) Apri Agus. Saat ini Dosen Jurusan Kesehatan dan Rekreasi Fakultas Ilmu Keolahragaan Universitas Negeri Padang

5) Rifhaatul Hanifa. Saat ini Mahasiswa Jurusan Kesehatan dan Rekreasi Fakultas Ilmu Keolahragaan Universitas Negeri Padang 
tidak terlalu mengalami kelelahan dan tidak ada keram otot yang dirasakan pada saat tes akhir.

Berdasarkan pengukuran tes awal daya tahan kecepatan tersebut, ternyata kemampuan daya tahan kecepatan atlet balapsepeda Kota Padang adalah 196,26. Selanjutnya diberikan perlakuan dengan memberi minuman suplemen EFS kemudian dilakukan tes akhir dengan menggunakan instrument yang sama. Dari pengukuran tersebut diperoleh hasil dengan peningkatan rata-rata daya tahan kecepatan berubah menjadi 193,27. Berdasarkan perlakuan yang diberikan pada saat tes akhir maka diperoleh hasil bahwa terdapat pengaruh pemberian suplemen EFSterhadap peningkatan daya tahan kecepatan. Hal ini terbukti secara signifikan, dimana setelah dilakukan uji " $\mathrm{t}$ " diperoleh hasil $\mathbf{t}_{\text {hitung }}=\mathbf{9 , 8 1}>\mathbf{t}_{\text {tabel }}=\mathbf{2 . 7 8}$.

\section{KESIMPULAN DAN SARAN}

\section{Kesimpulan}

Berdasarkan analisis datahasil penelitian dan pembahasan yang telah di uraikan sebelumnya, maka dapat disimpulkan bahwa: Pemberian suplemen Electrolyte Fuel System dapat berpengaruh terhadap daya tahan kecepatan atlet balap sepeda Kota Padang. Hal ini dibuktikan dengan nilai $t_{\text {hitung }}(9,81)>t_{\text {tabel }}(2,78)$.

\section{Saran}

Berdasarkan pada kesimpulan yang telah dikemukakan di atas, maka disarankan:

a. Kepada Pengurus Pengcab ISSI Kota Padang agar selalu memperhatikan dan memberikan asupan tambahan dan suplemen terhadap atlet.

b. Kepada Pelatih diharapkan untuk menyediakan suplemen Electrolyte Fuel System waktu mengikuti perlombaan.

c. Kepada Peneliti selanjutnya agar dapat melakukan penelitian dengan kajian yang lebih mendalam dan sampel yang lebih banyak, dan menggunakan alat tes yang lebih canggih.

5) Apri Agus. Saat ini Dosen Jurusan Kesehatan dan Rekreasi Fakultas Ilmu Keolahragaan Universitas Negeri Padang

5) Rifhaatul Hanifa. Saat ini Mahasiswa Jurusan Kesehatan dan Rekreasi Fakultas Ilmu Keolahragaan Universitas Negeri Padang 


\section{REFERENSI}

Agus Apri. 2012. Olahraga Kebugaran Jasmani. Padang: Sukabina Press.

Anggraini Rani. 2009. Faktor-faktor yang Literatur.Depok. Fakultas Kesehatan Masyarakat UI.

Arsil. 1999. Pembinaan Kondisi Fisik. Padang: Fakultas Ilmu Keolahragaan UNP.

Aziz Nugroho Yusuf. 2013. Pengaruh Pemberian Core Stability Exercise Terhadap

Back Pain Pyogenik Pada Atlet Balap Sepeda.Surakarta. FIK Universitas Muhammadiyan Surakarta.

Bafirman, Apri. 2010. Pembentukan Kondisi Fisik. Malang: Wineka Media.

Edmund. 1999. Bersepeda Dengan Teknologi Tinggi. Jakarta: RajaGrafindo Persada.

Elizabeth dkk. 2011. Running, Cycling \& Fitness Training. Annes Publishing.

Mintaraga Teguh. 2015. Gambaran Kecepatan Atlet Balap Sepeda ISSI Pengprov

Sumatera Barat.Padang : Universitas Negeri Padang.

Pekik Djoko Irianto. 2007. Panduan Gizi Lengkap Keluarga dan Olahragawan. Yogyakarta: Penerbit Andi.

Street Mortimer.2016. Total Road Cycling.London: Cartlon Books.

Sugiyono. 2008. Metode Penelitian Kuantitatif Kualitatif dan R\&D.Bandung Alfabeta

Syafruddin. 2011. Ilmu Kepelatihan Olahraga. Padang: UNP Press. . 1999. Ilmu Kepelatihan Olahraga. Padang: UNP Press.

Zalfendi. 2011. Gizi Olahraga. Padang: Sukabina Press.

5) Apri Agus. Saat ini Dosen Jurusan Kesehatan dan Rekreasi Fakultas Ilmu Keolahragaan Universitas Negeri Padang

5) Rifhaatul Hanifa. Saat ini Mahasiswa Jurusan Kesehatan dan Rekreasi Fakultas Ilmu Keolahragaan Universitas Negeri Padang 